\title{
Lexical Means of Verbalization of Uncertainty in the Arabic Language on the Example of Modern Best Sellers
}

\author{
Vladimir N. Denisenko ${ }^{1}$, Natalia S. Kalinina ${ }^{2}$ \\ ${ }^{1,2}$ Peoples' Friendship University of Russia (RUDN University) \\ 6, Miklukho-Maklaya street, Moscow, 117198, Russian Federation \\ 1'denisenko-vn@rudn.ru
}

\begin{abstract}
The article studies the peculiarities of verbalizing the category of ambiguity on the material of English literary texts translated into Arabic. Seven texts of writers-postmodernist - J. Barnes, T. McCarthy, I. McEwan, D. Lodge, D. Mitchell, were chosen to be analyzed. The subject of the category of ambiguity research is both logic and philosophical, and linguistic. Lexemes denoting ambiguity are described in terms of their belonging to semantic (thematic) fields, including their contrastive and stylistic properties. There are involved proper lexical units denoting ambiguity, and contextual, occasional means, while their dictionary definitions do not reveal the semes of ambiguity. The study deals with the role and functions of nominative units reflecting ambiguity and uncertainty of the world contemporary literary discourse through translation into Arabic. The methodology is based on the functional interaction of lexis and grammar as one of the systemic linguistics principles. The study conclusions proceed from the provision on the Arabic language to demonstrate the system of various lexical means to express the ambiguity category, and their determinant to be implied in paradigmatic relations of language system, and syntagmatic relations between textual semantic units which both explain grammar structure of language and the nature of semantic correlations in its lexical subsystem. The authors draw a conclusion that both English and Arabic languages possess universal extralinguistic meaning of nominative ambiguity, while the semantic field nucleus fulfils the crucial function to select and assort proper means and units to realize the ambiguity category in texts. Differentiation of ambiguity nominations according to their application is not homogeneous due to lexical nominations making up the main means to realize ambiguity principle as both semantic and grammatical category. In course of studying the topic issue it seems adequate to study the topic of ambiguity conceptualization in languages of different structure and arrange the means to verbalize the ambiguity concept using the method of systemic comparison.
\end{abstract}

Key words: Arabic language, marking, uncertainty, nomination, semantic field, system

\section{Acknowledgment:}

The reported study was funded by RFBR according to the research project № 19-012-00014 «Reconstruction of the content of the conceptual fields of systemic linguistics».

\section{Article history:}

Received: 01.10.2019

Accepted: 15.12.2019

(C) Денисенко В.Н., Калинина Н.С., 2020.

(c) (i) This work is licensed under a Creative Commons Attribution 4.0 International License https://creativecommons.org/licenses/by/4.0/ 
For citation:

Denisenko, V.N. \& Kalinina, N.S. (2020). Lexical Means of Verbalization of Uncertainty in the Arabic language on the example of Modern Best Sellers. RUDN Journal of Language Studies, Semiotics and Semantics, 11(1). 36-47. doi: 10.22363/2313-2299-2020-11-1-36-47

\title{
Лексические средства вербализации неопределенности в арабском языке на примере современных бестселлеров
}

\author{
В.Н. Денисенко ${ }^{1}$ Н.С. Калинина ${ }^{2}$ \\ 1,2 Российский университет дружбы народов \\ ул. Миклухо-Маклая, 6, Москва, Российская Федераџия, 117198 \\ 1denisenko-vn@rudn.ru
}

В статье рассматриваются особенности вербализации неопределенности на материале переведенных на арабский язык англоязычных художественных текстов. Материалом исследования явились семь художественных текстов постмодернистов Дж. Барнса, Т. МакКарти, И. МакЮена, Д. Лоджа, Д. Митчелла. Предметом исследования является логико-философская и как лингвистическая категория неопределенности. Лексемы, которые обозначают неопределенность, анализируются с точки зрения принадлежности к семантическим (тематическим) полям, а также в контрастивном и стилистическом аспектах. Рассмотрены как лексические единицы, имеющие значение неопределенности, так и контекстуальные, окказиональные средства, словарные толкования которых не содержат семы неопределенности. В исследовании описывается роль и функции номинаций неопределенности элементов современного мирового художественного дискурса на примере перевода на арабский язык. Методологией исследования стал разработанный в системной лингвистике принцип функционального взаимодействия лексики и грамматики. Выводы исследования включают тезис о том, что арабский язык демонстрирует систему разнообразных лексических средств выражения принципа неопределенности; детерминанта входит в парадигматические отношения языковой системы и в синтагматические отношения между текстовыми семантическими единицами, что объясняет грамматический строй языка и природу семантических связей в лексической системе. Авторы делают вывод о том, что английский и арабский языки имеют универсальное внеязыковое значение неопределенности наименования; детерминирующая функция ядра семантического поля заключается в подборе соответствующих единиц при реализации в тексте категории неопределенности. Дифференциация номинаций неопределенности по отраслям применения не является равномерной, т.к. лексические наименования - это основное средство текстовой реализации принципа неопределенности как семантической и грамматической категории. В рамках исследования данной проблемы представляется возможным изучить вопросы концептуализации неопределенности в разноструктурных языках и рассмотреть средства и реализацию вербализации концепта неопределенности с помощью метода системного сопоставительного анализа.

Ключевые слова: арабский язык, маркированность, неопределенность, номинация, семантическое поле, система

\section{Благодарность:}

Исследование выполнено при финансовой поддержке Российского фонда фундаментальных исследований в рамках научного проекта № 19-012-00014 «Реконструкция концептуального содержания понятийных полей системной лингвистики». 


\section{История статьи:}

Дата поступления: 01.10.2019

Дата приема в печать: 15.12.2019

\section{Для цитирования:}

Денисенко В.Н., Калинина Н.С. Лексические средства вербализации неопределенности в арабском языке на примере современных бестселлеров // Вестник Российского университета дружбы народов. Серия: Теория языка. Семиотика. Семантика. 2020. Т. 11. nо 1. С. 3647. doi: 10.22363/2313-2299-2020-11-1-36-47

\section{Introduction}

In course of mastering the real surrounding himenvironment, a man perceives everything new and anything incomprehensive as undetermined, while uncertainty and doubt used to accompany progress and served as its strong impact. Proceeding from the thesis understanding language as a reflection of every aspect of existence, one may suppose that there are all possible prerequisites for language ipse sui and any natural language as well (e.g., Arabic) to possess enough means to realize uncertainty both as logic and philosophical category and linguistic one. This objective rule lays in the basis of the subject of our research of the uncertainty category.

Lexical and grammatical means of the Arabic language let us clearly and variably verbalize the status of uncertainty in speech. However, to reveal the specifics of textual realization in the light of modern linguistics based on the absolutization of uncertainty, the demand to analyze manifestation of its means arises in modern literary texts as well. For the purpose we used the resources of contrastive linguistics and referred to English bestsellers' texts translated into Arabic. The choice of literary samples is stipulated by the further possibility to enlarge the list of languages under comparison which previews vast perspectives to establish interaction of specific partial grammatical categories and the general morphological type of contrasting languages.

\section{Research Material}

The article analyzes 7 literary texts of the $21^{\text {st }}$ century postmodernist writers, namely: «The Sense of an Ending» by J. Barnes, «Remainder» by T. McCarthy, «Saturday», «On Chesil Beach», «Atonement» by I. McEwan, «Deaf Sentence» by D. Lodge, «Cloud Atlas» by D. Mitchell making up 2114 pages in Arabic and English for comparison.

Among the total variety of Arabic nominations of uncertainty (2151 lexical units) the analyzed texts contain 1189 lexemes (55\% of the total) belonging to 18592 context (in average, each lexical unit is used 15 times). It's a solid rate index taking into account that the general register includes rarely used words as well (terms and slang). Such recurrence of textual revelations of Arabic concept reflects its significance for the modern Arabic linguistic conscience.

\section{Analysis of Samples}

Empirical analysis demonstrated that uncertainty nominations are represented in all analyzed texts and correlate with the lining of the nominative field of the concept 
إمبدأ الريبةن. To objectivize the concept, we involved contextual, occasional means and

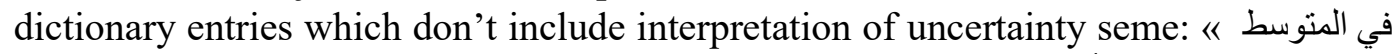

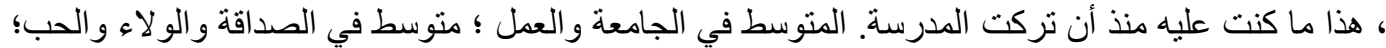

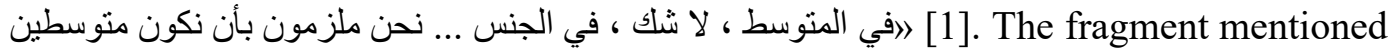

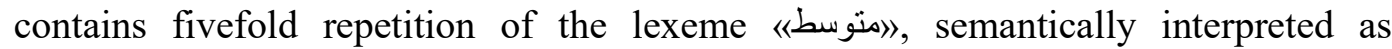
(نموذجية لمعظم الناس والأثياء《) and approximated to uncertainty, but not equal to it. In the context lexical unit obtains the meaning of mediocrity, intermediate condition.

Distribution of the representation degree of lexis in the texts as percentage of the total number of actualized lexemes assumes the following presentation (Fig. 1):

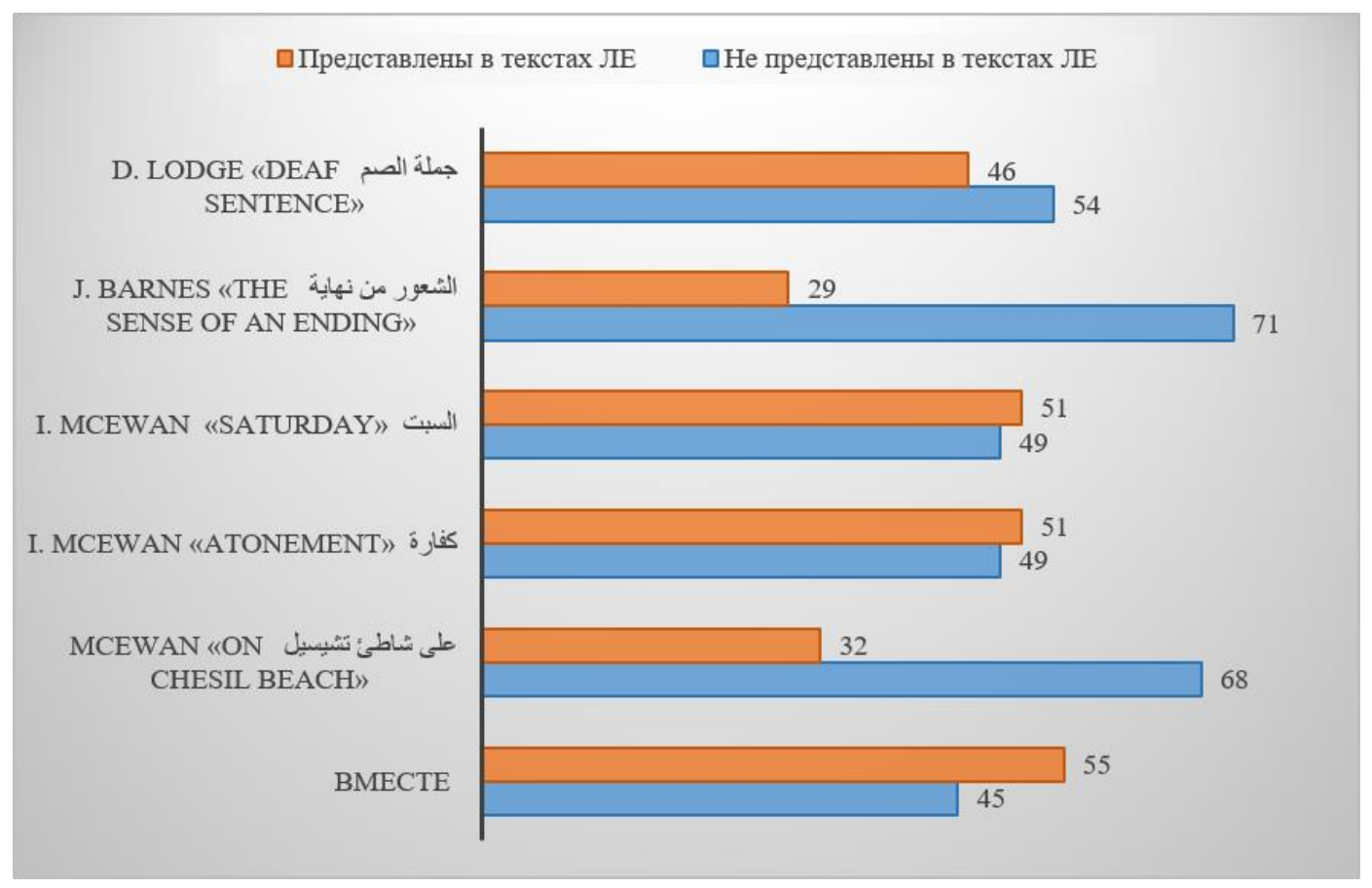

Fig.1. Textual implementation of Arabic nominations of uncertainty in 21st-century British bestsellers in Arabic

While reviewing the distribution of nominations accepted, the regulation was revealed: each text contains dominant lexemes which are dominating in quantity or number and concentrate around themselves other components of the nominative field. Quantitative analysis showed that in the processed texts there exist key elements of the nominative field of the concept 《الريبة مبدأي (percentage of the total number of the concept lexical representations in each text) (Table 1).

The investigated empirical material demonstrates that recurrent key lexemes to denote uncertainty in the analyzed texts of different writers are practically coinciding.

The review of the trend manifesting itself after the calculation of every key nomination of uncertainty expression we'd present in the diagramme. 
The most frequent lexical units with a sevenfold of uncertainty in 21 st-century British bestsellers in Arabic

\begin{tabular}{|c|c|c|c|c|c|c|}
\hline \multicolumn{3}{|c|}{ McEwan } & D. Mitchtll & McCarthy & J. Barnes & D. Lodge \\
\hline «Saturday» & $\begin{array}{l}\text { شاطئ على / تشيسلى } \text { /On Chesil } \\
\text { Beach» } \\
\text { Beach }\end{array}$ & \begin{tabular}{|l|} 
«Atonement» \\
«At
\end{tabular} & $\begin{array}{l}\text { أطلسابة / } \\
\text { «Cloud } \\
\text { Atlas» }\end{array}$ & $\begin{array}{l}\text { بقية / } \\
\text { «Remainder» }\end{array}$ & $\begin{array}{l}\text { من الشعور / «ماية /The } \\
\text { Sense of an } \\
\text { Ending» }\end{array}$ & / جملة الصم \\
\hline half - 30.36\% & $\begin{array}{l}\text { half - } \\
29.21 \%\end{array}$ & half $-31.54 \%$ & $\begin{array}{l}\text { half - } \\
28.3 \%\end{array}$ & half - $43.54 \%$ & $\begin{array}{l}\text { Question - } \\
6.45 \%\end{array}$ & $\begin{array}{l}\text { Not } \\
\text { knowing - } \\
19 / 7 \%\end{array}$ \\
\hline $\begin{array}{l}\text { Not knowing - } \\
10.9 . \%\end{array}$ & $\begin{array}{l}\text { Not } \\
\text { knowing - } \\
16.4 \%\end{array}$ & $\begin{array}{l}\text { Question - } \\
11.86 \%\end{array}$ & $\begin{array}{l}\text { Not } \\
\text { knowing - } \\
16.6 \%\end{array}$ & $\begin{array}{l}\text { Not knowing - } \\
14.9 \backslash \%\end{array}$ & \begin{tabular}{|l} 
Not \\
knowing - \\
$19 / 7 \%$ \\
\end{tabular} & $\begin{array}{l}\text { Question /- } \\
6 \%\end{array}$ \\
\hline $\begin{array}{l}\text { Question - } \\
10.53 \% \text {. }\end{array}$ & $\begin{array}{l}\text { Question } \\
11.23 \% \\
\end{array}$ & $\begin{array}{l}\text { Not knowing - } \\
11.37 \%\end{array}$ & $\begin{array}{l}\text { Question - } \\
6.45 \%\end{array}$ & \begin{tabular}{|l} 
Question - \\
$6.45 \%$ \\
\end{tabular} & half $-30.36 \%$ & $\begin{array}{l}\text { probable - } \\
16.42 \% \\
\end{array}$ \\
\hline doubt $-7.69 \%$ & $\begin{array}{l}\text { doubt - } \\
711.23 \%\end{array}$ & doubt $-7.83 \%$ & $\begin{array}{l}\text { doubt - } \\
8.9 \%\end{array}$ & $\begin{array}{l}\text { Vague - } \\
9.41 \%\end{array}$ & \begin{tabular}{|l|} 
Mystery - \\
$9.68 \%$
\end{tabular} & $\begin{array}{l}\text { half - } \\
13.87 \%\end{array}$ \\
\hline $\begin{array}{l}\text { probable - } \\
7.29 \%\end{array}$ & $\begin{array}{l}\text { Vague - } \\
6.74 \%\end{array}$ & Vague-5.39\% & $\begin{array}{l}\text { Worry - } \\
7.5 \%\end{array}$ & Dizzy $-5.1 \%$ & \begin{tabular}{|l} 
probable - \\
$8.39 \%$
\end{tabular} & \begin{tabular}{|l|} 
Worry - \\
$8.76 \%$ \\
\end{tabular} \\
\hline Vague $-9.41 \%$ & $\begin{array}{l}\text { probable - } \\
16.42 \%\end{array}$ & $\begin{array}{l}\text { probable - } \\
16.42 \%\end{array}$ & $\begin{array}{l}\text { Mystery - } \\
9.68 \%\end{array}$ & $\begin{array}{l}\text { probable - } \\
16.42 \%\end{array}$ & $\begin{array}{l}\text { Unsure - } \\
7.74 \%\end{array}$ & \begin{tabular}{|l} 
doubt - \\
$7.69 \%$ \\
\end{tabular} \\
\hline
\end{tabular}

Preferential writers' use of definite nominations to denote uncertainty is almost identical and could serve as the evidence for:

1) chosen lexemes belong to the core of the nominative field of the literary concept مبدأ الريبة) and reflect general regularities of the apprehension of the concept by Arabic mentality bearers;

2) verbalization of disorder or uncertain state is inherent of literary postmodern practices considering absolutization of uncertainty and is realized in all literary texts having similar indexes among the texts of different writers, e.g., I. McEwen and D. Mitchell;

3 ) for objectivizing uncertainty by means of relevant factors one has to refer to writes' arrangements and style. It is proved with identical indexes of sets of nominations in the texts of the same writer (I. McEwan), as in the left sector of the diagramme (picturing indexes of three texts of one and the same writer) the distribution of lexemes coincides and it gives the evidence of similarity of writer's style of the texts.

We esteem the individual writers' preferences in using lexemes which do not belong to the core nominations of uncertainty help expose their personal arrangements of each text. Besides, language preferences of the writers are motivated by stories. Thus, in the novel by J. Barnes, recurrent lexemes 《غير متأكد) الغموض and express protagonist's ambition to solve a mystery of a friend's death and uncertainty of search results; "مصاب بدوار》 lexeme of T. McCarthy imply physical and psychological faults

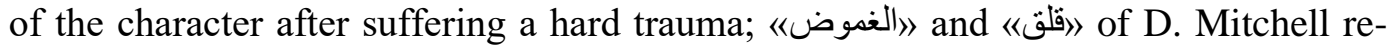
flect multiple secrets of characters and worries after they were solved; in the novel by D. Lodge lexeme 《قلق) denotes permanent character's agitation concerning intimate relations with a student of his.

Graphic presentation of a number of lexeme use in each analyzed text takes the form as in Fic. 2 (the percentage of the total fixed nominations). To make a note, the 
words to undergo analysis were chosen together with all their derivatives (semes were registered, not word forms). If to sum up all nominations of uncertainty used by the

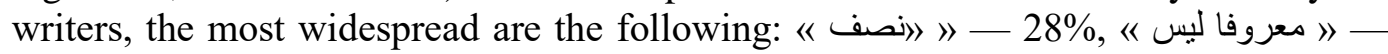

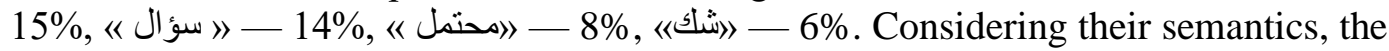
majority of the domain lexemes (4 and 5) express "subjective" uncertainty speaking in favour of their content subjectivation.

D . Lodge, «The Deaf Sentence»

T. McCarthy, «Remainder»

J. Barnes, «The Sense of an Ending»

I. McEwan, «Atonement»

I. McEwan, «On Chesil Beach»

I. McEwan, «Saturday»

D. Mitchell, «Cloud Atlas»

| نصف - «half»

" «doubt》 - شs

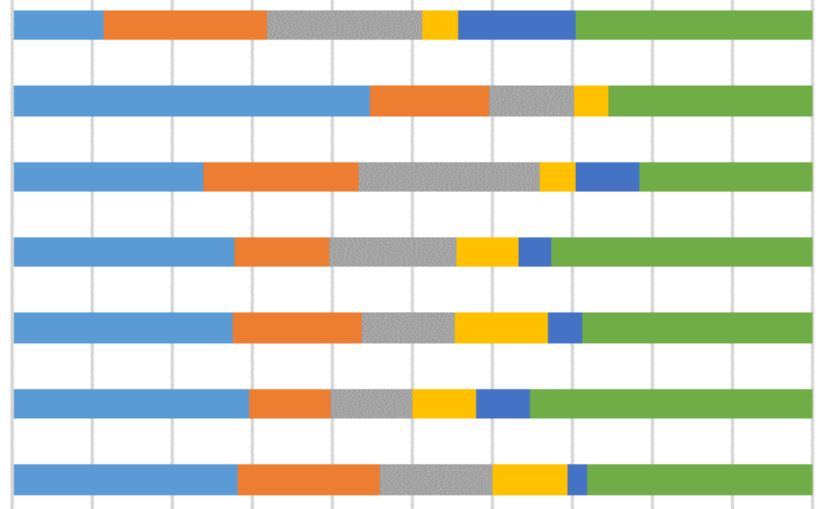

$\begin{array}{lllllllllll}0 \% & 10 \% & 20 \% & 30 \% & 40 \% & 50 \% & 60 \% & 70 \% & 80 \% & 90 \% & 100 \%\end{array}$

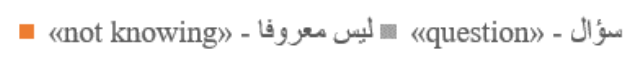

- «probable» - " - другие

Fig. 2. Distribution of the most frequent uncertainty nominations in texts

Proceeding from quantitative data, the correlation within the main five nominations of uncertainty looks like that:

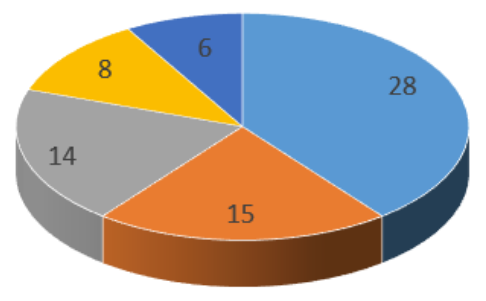

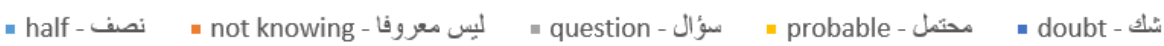

Fig. 3. The most frequently used LUs to denote uncertainty in British bestsellers in Arabic, \%

Quantitative indexes of these nominations in literary texts, lexis makes up the main five or $2 / 3$ of all lexical units bearing semantics of uncertainty, and just one third makes up other nominations. This ratio persists in each text (see: Fig. 9). So, to depict the impression of instability and uncertainty in the English language texts there are largely used nominations of indistinct uncertainty seme and their associates. 
The rest of usage include one third of sampled nominations $(31 \%$ in number almost identical to the usage of a sole lexeme 《نصف)). Only two of the lexemes (《ثك)》 и 《إسوال belong to the core of the nominative field of the concept. It means that in literary texts, to reflect the literary "universal and pervasive" uncertainty the writes go in for using lexical means of the near-core zone and periphery of the nominative field of the concept, as the zones mentioned do not have exact limits, and such lexical means bear ambivalence. Genre features also demand the writers use expressiveness that contradicts the unambiguity of nominations and facilitate the textual use of peripheral lexical units. The obtained transposed quantitative indexes of the nominative field of the literary concept of uncertainty are exposed as a distribution of its verbalization as the core of the nominative field (Fig. 4):

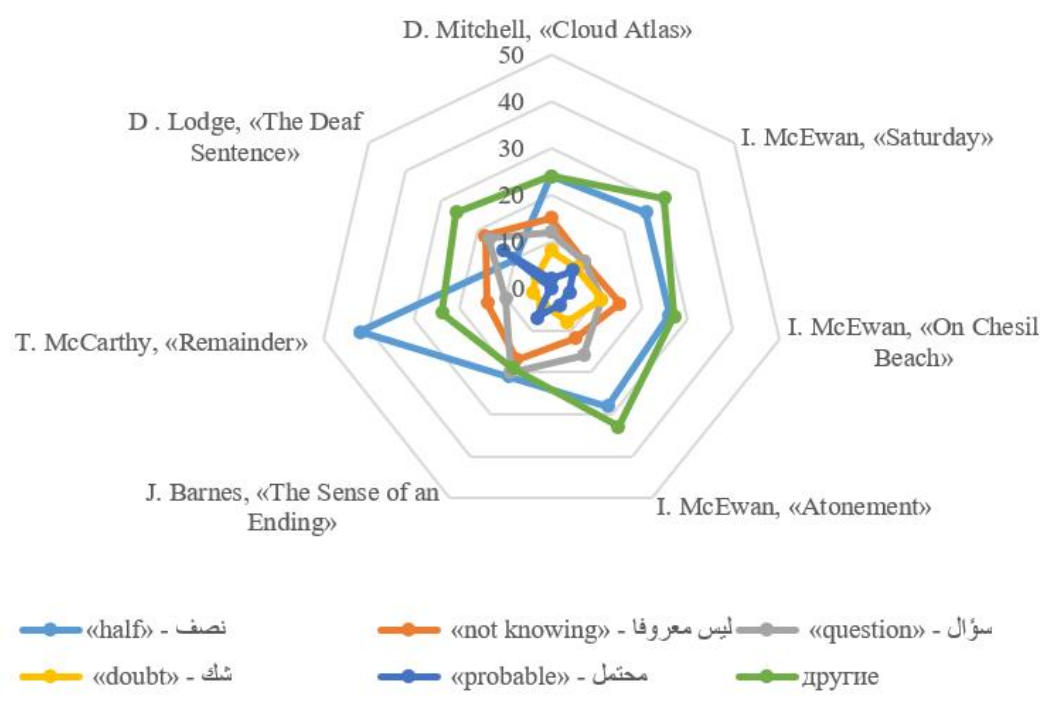

Fig. 4. Lexical filling of the core of the nominative field of the literary concept " مجهول شیىء"

Fig. 4 shows the approximation of lexemes to the core of the nominative field of the literary concept 《شى مجهول). The analysis of the text revealed the crucial aspect to objectivize the concept of uncertainty: several nominations acquire the functions of uncertainty markers ibn the text only (uncertainty semes are not reflected in the dictionary entries). It gives the evidence of the existing redistribution among the zones of the nominative field of the concept - peripheral elements become the core ones which is most typical of the modern Arabic literary texts., as "transfer of core and peripheral layers of the concept is observed during the periods of cultural arrangements changes, spiritual crisis and first of all, in the literary discourse" [2].

Quantitative textual indexes demonstrated that the ratio of a number of usage samples of lexical and morphological means made up about 1:2 (18591:31169). Despite much lesser amplitude of Arabic morphological means to express uncertainty, their functional characteristics and implicative potential let confirm the high productivity in use as the uncertainty markers. 
The domination of a lexeme «نصف》 over used in texts nominations of uncertainty (thesaurus analysis didn't find it among the core elements of the nominative field) proves non-compliance between the dictionary reflection of uncertainty (linguistic, reflected in the dictionary entries) and discourse (speech, which is actualized in literary texts). The central position of this lexical unit might be proved with a few factors. Firstly, it’s the lexeme’s semantics (شيء غير كامل ;جزئيا ولكن ليس نماماش) that provides its fragmentary, incomplete nature that is some ambiguity, vagueness. In this angle, for example, the character of T. McCarthy's novel «Remainder» perceives rather neutral

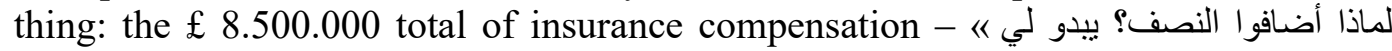
إفوضوي جدا ، هذا النصف :جزء من بقايا ، قطعة من المخلفات. The allusion on the half to add to the amount causes his embarrassment and dismay.

Instability of situation has got a broad expression in literary texts and provides to

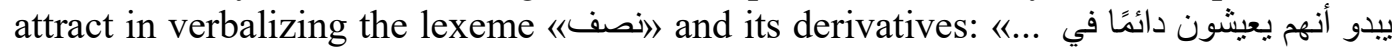
]3» حالة شبه فوضى ، مع نصف مساحة معيشتهم فقط قابلة للحياة]

For the sake of intensification of the uncertainty effect, within a sentence, British authors use a number of means of various linguistic levels, which serve to the singe aim - the objectivization of the atmosphere of instability in their texts: " قبل شهر أخبروا بعضهم البعض بأنهم كانوا في حالة حبب ، وكان ذلان بمثنابة إثارة وبعد ذلك سبب ليلة واحدة من الاستيقاظ

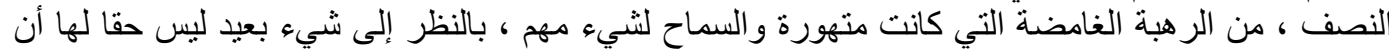
]4» [تعطي. Thanks to accumulating the means of various linguistic levels, and according to the excess principle, some fragments of literary narrative possess the high de-

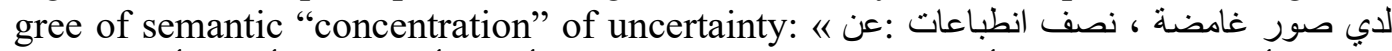

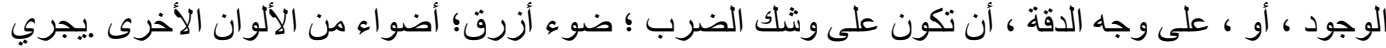

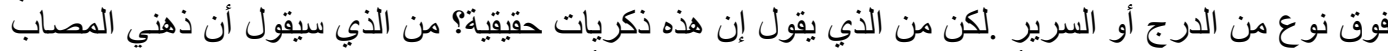

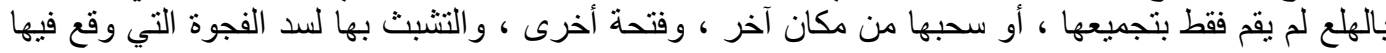
]5»] الحادث؟ Such textual arrangement of representatives is the general trend of the texts under review.

The second reason of this lexeme domination lies in its strong derivational potential, because as a morpheme «فن it could belong to any lexical unit despite its word-class attribution, and it makes grow the number of its textual usages. Thus, the novel by D. Mitchel «Cloud Atlas» counts 127 usages of 32 lexical units with «نصف》 component derived from the Arabic outspread (نصف معبأة ,نصف منتهية ,خفية نصف), and individual authors' nonce formations like (نصف الثقلبات, اول نزفيز). One of the derived lexemes is used as a chapter title of the novel (أول لغز لويز اري) (حياة النصف)).

A great many of such derivatives are contained in other analyzed texts: "Atone-

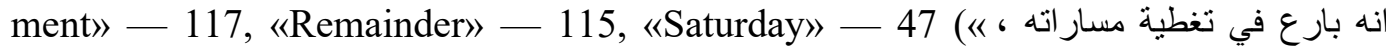

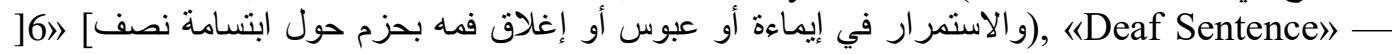

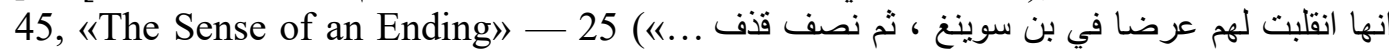
]7》 (مقلاة ساخنة في بالوعة الرطب), «On Chesil Beach» — 20. The total of usages of the

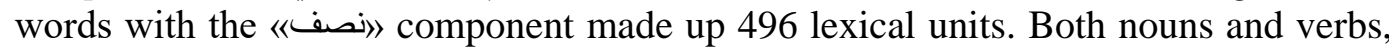
adjectives and participles might combine with «نصف

Thirdly, as an independent lexeme, it is functionally flexible and could belong to various parts of speech in the text as those:

- a noun (in sentences to fulfil functions of a subject, a part of compound nominal predicate, an apposition): «7" [كن هذا كان نصفها فقط. C. 80]; 
- a determinative (in text, attribute): "دابير أي هناك يكون لن ، فنثل هنالك يكون عندما نص $>$ [8];

- an adverb (the adverbial modifier of modus operandi): "كض سيسيليا ناليس نصفها ]9» [ع زهورها على طول الطريق الذي مر به النهر.

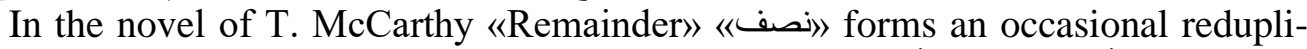

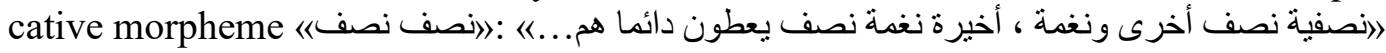
[10. C. 84]. Reduplicated compounds demonstrate semantic intensity, which is why we traet them as individual authors' nonce words, because we could fix such formation in a single text of a single writer.

The data obtained shows that among other nominations of the بمبدأ الريبة) concept in the analyzed texts prevail:

مثل وكانت ، العنابر في وكذلك الثوارع في هنالك كان الذي الارتياح عدم تذكرت《: : (246) ظلام (نفسه الظلام (11. C. 260-261];

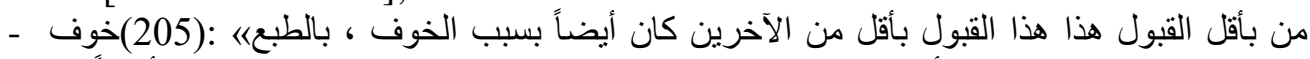

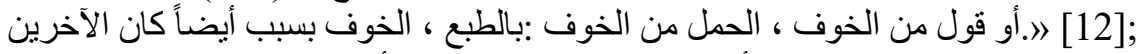

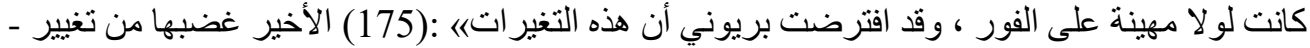

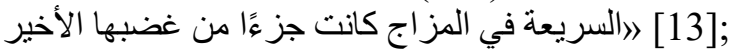

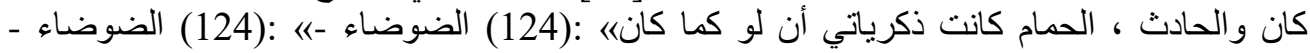

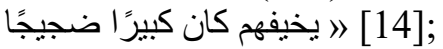

، كارثية نهاية إلى تصل أن يمكن للحضارة الممكنة الطرق من العديد هنالك؛ :(117) حدوثه جائز [15];

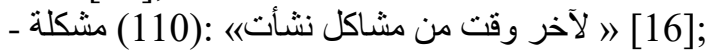

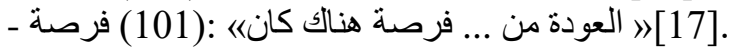

There the seme of uncertainty is not the main dictionary meaning, however, it is used in the txt and is contextually supported with the concentration of meanings of semantically similar lexemes. Due to the "seme repletion" (the term was introduced by M.V. Nikitin [18]) and coordination of synonymic lexis in the text, we notice the stronger direct nominative meaning of uncertainty which is overlapping wit contextual meanings of a broad range of lexical units.

Key words of a text and their most frequent associates make up the core elements of the nomination field of the concept [20], and semantic dominants of texts, "the background of stylistic devices speaking of the authors' textual strategies" [21]. The analysis carried out lets qualifying the concept «الريبة مبدأيto be the text creating component of British literary texts, which according to the arrangement of the absolutization of uncertainty also belongs to the modern literary Arabic system.

Even more important aspect of content development of literary texts considering semantics of exposed lexemes, is the review in terms of "double encoding". According to the theory of postmodernism, a message exists s a complex interaction of various codes (which R. Bartes defines as "super textual organization of meanings imposing the image of a certain structure" [22]). According to D. Fokkema, there are such codes of literary text:

- linguistic code (code of natural language - here Arabic);

- literature code (as the perception of literary texts as coherent ones);

- genre code (expectations of genre qualification of a text);

- idiolect of a writer (recurrent features of individual style); 
- postmodernism code as a literary trend (realization of literary arrangements and poetics) [23].

Specifics of such encoding is a simultaneous realization of codes and their concurrence in process of receiving a text by a reader: "Every code limits and denounces the actions of other codes forming and approving its own choice of linguistic units and their arrangement" [24].

\section{Conclusions}

Finally, the analysis of the modern world literary discourse in the Arabic variation demonstrated the Arabic contains a large amount of various lexical means to express the uncertainty principle.; thy make up a coherent system and subordinate definite regulations. Cultural and etymological markedness of some uncertainty nominations (despite using the world bestsellers for analysis) deals with specifics of their perception by Arabic language bearers. It limits their usage and brings difficulties for perception, still, at the same time, it broadens their potential as such markedness causes new senses, correlating with the established ones. Arabic and English languages express the universal extralinguistic sense of uncertainty nomination - a textual lexical unit as a sign of an object not yet balanced in the exact communicative act - through pecific linguistic meanings of the correlated lexemes and grammatical the forms.

Lexis denoting various aspects of uncertainty, embraces a broad span of human activity and communication. The distribution among the application spheres of uncertainty nominations is not even. Thus, lexical nominations are a powerful means of textual realization of the uncertainty principle both as semantic and grammatical category. The carried out research also showed that the notion of determinant put forward within systemic theory of language by G.P. Melnikov, could be applied both to systemic paradigmatic relations and syntagmatic relations between textual semantic units, as well as the explanation not only the grammatical structures of language, but also the nature of semantic ties in lexical system. The high degree of synthetism and orientation of the Arabic language determinant to the maximal grammatization of semantic categories embodies into grammatical expression of uncertainty meaning in close connection of lexical and grammatical means to realize this category.

The analysis of semantics of textual lexical units and grammatical forms bring the conclusion of determinative role of the core of semantic field in arranging proper units in course of textual realization of uncertainty category which is the evidence of systemic arrangement of semantic field both in a national language as a whole and a single separate text.

Among the perspectives of further research, one might name a range of issues connected with conceptualization of uncertainty in languages of different structure, in particular, studying mechanisms and means to verbalize the uncertainty concept applying systemic comparative anlysis.

\section{References}

1. Barnes, J. (2011). The Sense of an Ending. London: Jonathan Cape. / J. إنهاء بمعنى بارنز / J. . بارنز https://www.kutub-pdf.com/book/\%D8\%A7\%D9\%84\%D8\%A5\%D8\%AD\%D8\%B3\% 
D8\%A7\%D8\%B3-D8\%A8\%D8\%A7\%D9\%84\%D9\%86\%D9\%87\%D8\%A7\%D9\%8A\%

D8\%A9. html

2. Sulimenko, N.E. (2008). Text and aspects of its lexical analysis N.E. Sulimenko (ed.). Moscow: Flint: Nauka. (In Russ.).

3. Lodge, D. (2009). Deaf Sentence. London: Penguin Books. لودج) D. لوملة الصم 2010, E-resource).

4. McEwan I. (2007b). On Chesil Beach. London: Jonathan Cape.

5. McCarthy, T. (2006). Remainder. London: Alma Books.

6. McEwan, I. (2006). Saturday. London: Vintage Books.

7. Barnes, J. (2011). The Sense of an Ending. London: Jonathan Cape.

8. McEwan, I. (2006). Saturday. London: Vintage Books.

9. McEwan, I. (2007a). Atonement. London: Vintage Books.

10. McCarthy, T. (2006). Remainder. London: Alma Books.

11. McEwan, I. (2007a). Atonement. London: Vintage Books.

12. Barnes, J. (2011). The Sense of an Ending. London: Jonathan Cape.

13. McEwan, I. (2007a). Atonement. London: Vintage Books.

14. McCarthy, T. (2006). Remainder. London: Alma Books.

15. Lodge, D. (2008). Deaf Sentence. London: Penguin Books. لودج) D. لوج 2010, E-resource).

16. Mitchell, D. (2004). Cloud Atlas. New York: Random House.

17. McEwan, I. (2007a). Atonement. London: Vintage Books.

18. Nikitin, M.V. (2007). Course of linguistic semantics. SPb: RSPU in. A.I. Herzen. (In Russ.).

19. Mitchell, D. (2004). Cloud Atlas. New York: Random House.

20. Popova, Z.D. \& Sternin, I.A. (2007). Semantic and cognitive analysis of language. Voronezh: Istoki publishing House. (In Russ.).

21. Sulimenko, N.E. (2009). Text and aspects of its lexical analysis. Moscow: Flint: Nauka. (In Russ.).

22. Arshinov, V.I., Lukyanchuk, B.S. \& Nikolsky, A.E. et all (2017). Semiotics of communicative waves of "subconscious": on topical issues of structural semiotics. Moscow: Sputnik. (In Russ.).

23. Douwe Wessel, Fokkema. (2000). Knowledge and Commitment: A Problem-Oriented Approach to Literary Studies.

24. Ilyin, I.P. (2001). Postmodernism. Dictionary of terms. Moscow: Inion ras-intrada. (In Russ.).

\section{Библиографический список}

1. Barnes J. The Sense of an Ending / J. Barnes. London: Jonathan Cape, 2011. Режим доступа: J. بارنز بـارنز . https://www.kutub-pdf.com/book/\%D8\%A7\%D9\%84\%D8\%A5\%D8\%AD\% D8\%B3\%D8\%A7\%D8\%B3-D8\%A8\%D8\%A7\%D9\%84\%D9\%86\%D9\%87\%D8\%A7\%D9\% 8A\%D8\%A9.html. p. 60.

2. Сулименко H.Е. Текст и аспекты его лексического анализа. М.: Флинта: Наука, 2009.

3. Lodge D. Deaf Sentence. London: Penguin Books, 2008. 2010, الجملـة الصـم . لـودج) E-resource).

4. McEwan I. On Chesil Beach. London: Jonathan Cape, 2007b.

5. McCarthy T. Remainder. London: Alma Books, 2006.

6. McEwan I. Saturday. London: Vintage Books, 2006.

7. Barnes J. The Sense of an Ending. London: Jonathan Cape, 2011.

8. McEwan I. Saturday. London: Vintage Books, 2006.

9. McEwan I. Atonement. London: Vintage Books, 2007a.

10. McCarthy T. Remainder. London: Alma Books, 2006.

11. McEwan I. Atonement. London: Vintage Books, 2007a.

12. Barnes J. The Sense of an Ending. London: Jonathan Cape, 2011.

13. McEwan I. Atonement. London: Vintage Books, 2007a. 
14. McCarthy T. Remainder. London: Alma Books, 2006.

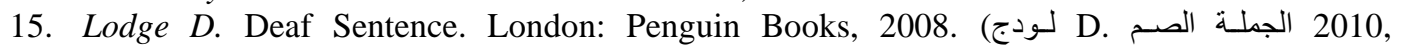
E-resource).

16. Mitchell D. Cloud. New York: Random House, 2004.

17. McEwan I. Atonement. London: Vintage Books, 2007a.

18. Никитин М.В. Курс лингвистической семантики. СПб.: РГПУ им. А.И. Герцена, 2007.

19. Mitchell D. Cloud Atlas. New York: Random House, 2004.

20. Попова З.Д., Стернин И.А. Семантико-когнитивный анализ языка. Воронеж: Изд-во «Истоки», 2007.

21. Сулименко Н.Е. Текст и аспекты его лексического анализа. М.: Флинта: Наука, 2009.

22. Аршинов В.И., Лукьянчук Б.С., Никольский А.Е. и др. Семиотика коммуникативных волн «подсознания» (Semiotics of communicative waves of "subconscious"): к актуальным вопросам структурной семиотики. М.: Спутник, 2017.

23. 23.Douwe Wessel Fokkema. Knowledge and Commitment: A Problem-Oriented Approach to Literary Studies. Amsterdam; Philadelphia: J. Benjamins, 2000.

24. Ильин И.П. Постмодернизм. Словарь терминов. М.: ИНИОН PAH-INTRADA, 2001.

\section{Сведения об авторах:}

Денисенко Владимир Никифорович, доктор филологических наук, профессор, заведующий кафедрой общего и русского языкознания филологического факультета РУДН; сфера научHblx интересов: семантические и когнитивные исследования языка; теория семантического поля; контрастивный и сравнительный языковой анализ; e-mail: denisenko-vn@rudn.ru

Калинина Наталья Сергеевна, аспирант кафедры общего и русского языкознания филологического факультета Российского университета дружбы народов; научные интересы: лингвистическая семантика; e-mail: ke6831@yandex.ru

\section{Information about the authors:}

Vladimir N. Denisenko, DSc. in Philology, Full Professor, Head of the General and Russian Linguistics Department, Philological Faculty, RUDN University. The sphere of research includes semantic and cognitive language studies, theory of semantic fields, contrastive and comparative linguistic analyses; e-mail: denisenko-vn@rudn.ru

Natalia S. Kalinina, Post-graduate student of the General and Russian Linguistics Department, RUDN University; Interests: linguistic semantics; e-mail: ke6831@yandex.ru 